\title{
The Foot Shape of School Girls and Female Farm Workers in Northern Kyushu
}

\author{
Teruyuki HoJo and Tamiji NAKASHIMA \\ Department of Anatomy and Anthropology, School of Medicine, University of Occupational and \\ Environmental Health, Japan. Kitakyushu 807, Japan
}

\begin{abstract}
This is an anthropometric study of the foot shape of 23 school girls of Northern Kyushu. They live in Kitakyushu City and its suburbs. Their parents are descendants of people of Fukuoka Prefecture. While there was no significant difference regarding the footlength among these school girls and the other two groups of farm workers who lived in the rural areas of Northern Kyushu about two decades ago, these school girls had the narrowest feet with the smallest foot-index (a ratio of the foot-breadth to the foot-length) and the tallest stature. These physical features may be considered to be the result of the urban life and the differences of generation.
\end{abstract}

Key words: foot, narrowness, school girls, female farm workers.

(Received 28 May 1985)

\section{Introduction}

This study will make clear some differences among three ethnological groups regarding the shape of the foot of the female Kyushuites. The former study (Hojo et al., 1981) showed that the secular difference between the mean of the stature of the female Northern Kyushuites in 1973 and that of the standard Japanese was statistically significant at the level of $0.001 \%$ by the $t$-test; $t=12.3$. Furthermore, we described the secular unchangeability in relative sitting height of female Northern Kyushuites (Hojo et al., 1984).

But up to now we have no data regarding the anthropometric study of the foot of female Northern Kyushuites in Kitakyushu City. This study of the foot was made as one of the anthropological studies of Northern Kyushuites from the ethnological point of view.

Regarding the physical features of humans, we must consider both environmental and genetic differences. From this viewpoint the anthropological data of female Northern Kyushuites were compared with those of females who lived about two decades ago in two other districts in Fukuoka Prefecture; Minoshima village, a small island in those days, near Yukuhashi City in Northern Kyushu and Katsuma district in Shika town near Fukuoka City in those days. We described these groups as Minoshimaites (Iwanaga, 1956) and Shika-Katsumaites (To, 1959). 
Table 1. The numbers, the means and the standard deviations of foot-length, foot-breadth, foot-index and stature of school girls in Kitakyushu City

\begin{tabular}{lrrrrrrrr}
\hline & \multicolumn{3}{c}{ 17 years of age } & & \multicolumn{3}{c}{18 years of age } \\
\cline { 2 - 4 } \cline { 7 - 9 } \multicolumn{1}{c}{ Item } & $\mathrm{N}$ & Mean & SD & & $\mathrm{N}$ & Mean & SD \\
\hline Foot-length $(\mathrm{mm})$ & 15 & 223.9 & 7.75 & & 8 & 223.8 & 6.58 \\
Foot-breadth $(\mathrm{mm})$ & 15 & 89.7 & 4.03 & & 8 & 91.3 & 3.69 \\
Foot-index & 15 & 40.1 & 1.87 & & 8 & 40.8 & 1.14 \\
Stature $(\mathrm{cm})$ & 15 & 154.5 & 4.63 & & 8 & 153.0 & 3.19 \\
\hline
\end{tabular}

Table 2. The numbers, the means and the standard deviations of foot-length, foot-breadth, foot-index and stature of school girls compared with those of female Minoshimaites and Shika-Katsumaites in Northern Kyushu

\begin{tabular}{|c|c|c|c|c|c|c|c|c|c|}
\hline \multirow[b]{2}{*}{ Item } & \multicolumn{3}{|c|}{$\begin{array}{c}\text { School girls in } \\
\text { Kitakyushu City } \\
\text { (Hojo \& Nakashima, 1985) }\end{array}$} & \multicolumn{3}{|c|}{$\begin{array}{c}\text { Female } \\
\text { Minoshimaites } \\
\text { (Iwanaga, 1956) }\end{array}$} & \multicolumn{3}{|c|}{$\begin{array}{c}\text { Female } \\
\text { Shika-Katsumaites } \\
\left(T_{0}, 1959\right)\end{array}$} \\
\hline & $\mathrm{N}$ & Man & $\mathrm{SD}$ & $\mathrm{N}$ & Mean & $\mathrm{SD}$ & $\mathrm{N}$ & Mean & SD \\
\hline Foot-length $(\mathrm{mm})$ & 23 & 223.8 & 7.22 & 157 & 221.80 & 8.68 & 90 & 225.34 & 10.68 \\
\hline Foot-breadth (mm) & 23 & 90.3 & 3.91 & 157 & 95.69 & 4.59 & 90 & 95.40 & 5.02 \\
\hline Foot-index & 23 & 40.3 & 1.66 & 157 & 48.56 & 2.02 & 90 & 42.35 & 1.78 \\
\hline Stature $(\mathrm{cm})$ & 23 & 153.8 & 4.21 & 158 & 149.31 & 5.20 & 86 & 149.3 & 5.15 \\
\hline
\end{tabular}

\section{Materials and Method}

As shown in Table 1, female Northern Kyushuites were 17 and 18 year-old school girls of Orio Women's School, located in Kitakyushu City, Northern Kyushu. Their foot-length, foot-breadth and stature were measured according to Martin-Saller's anthropometric method (Martin \& Saller, 1957) and foot-indexes (a ratio of foot-breadth to foot-length) were obtained. Because there were no significant differences between these two groups, we combined these data of the two groups as shown in Table 2.

Furthermore, these school girls were compared with female Minoshimaites and female Shika-Katsumaites regarding the shape of the foot.

\section{Results and Discussion}

As shown in Table 2, the foot-length of these school girls in Kitakyushu City did not siginificantly differ from those of the other two (between these school girls and female Minoshimaites $(t=1.052, t(0.05 \%, f=178)<1.98)$; between these school girls and female Shika-Katsumaites $(t=0.653)$. But the foot-length of female Shika-Katsumaites was significantly longer than that of female Minoshimaites $(\mathrm{t}=2.832, P<0.01)$.

The foot-breadth of female Shika-Katsumaites was nearly equal to that of Minoshimaites, but that of the school girls of Kitakyushu City was significantly narrower than that 
of the narrower group, that of female Shika-Katsumaites $(\mathrm{t}=4.528, P<0.001)$.

Among these three ethnological groups the smallest foot-index (a ratio of foot-breadth to foot-length) was that of the school girls of Kitakyushu City. That is to say, their foot-indexes were significantly smaller than those of female Shika-Katsumaites, the second largest foot-index of the three $(\mathrm{t}=4.993, P<0.001)$. According to To $(1959), 75$ per cent of female Shika-Katsumaites were farm workers in those days (To, 1959). Their feet were broader than those of the school girls living about two decades later in Kitakyushu City.

Furthermore, school girls in Kitakyushu City showed the tallest stature among these three groups. The mean of their statures significantly differs from those of the other two groups which were nearly equal to each other $(\mathrm{t}>3.96, P<0.001)$.

In short, these school girls in Kitakyushu City have the narrowest feet and the tallest stature among these three groups. But their foot-lengths are nearly equal to those of the other two groups.

The ecological status of these school girls is their urban life which differs from the rural life of the other two groups. The differences between the Kitakyushu school girls and the other two groups are due to the differences of the ecological statuses and the generation difference.

\section{References}

Hojo, T., Takemoto, R. \& Shinoda, K. (1981): The secular unchangeability in relative sitting height of female Kyushuites. J. UOEH, 3: 203-205.

Hojo, T., Nakashima, T. \& Hirao, T. (1984): Stature, sitting height and relative sitting height of female Northern Kyushuites. J. UOEH, 6: 355-357.

Iwanaga, M. (1956): Anthropological studies of the population of Minoshima, Miyako-District, Fukuoka prefecture, Japan. Quart. J. Anthrop., 3: 210-246. (in Japanese with English summary).

Martin, R. \& Saller, K. (1957): Lehrbuch der Anthropologie. Bd. I. Gustav Fischer Verlag, Stuttgart. pp. $338-339$.

To, H. (1959): Somatological studies on the Katsuma and Hiro villagers, Shika-machi, Kasuyagun, Fukuoka prefecture, Japan. Quart. J. Anthrop., 6: 328-365. (in Japanese with English summary). 
北部九州の女子学生と女性農民の足型

北條 暉幸・中島 民治

産業医科大学第一解剖学教室

要 旨： 北九州市とその郊外に住む 23 人の女子学生の足型の計測学的研究である. 彼等の両親は 福岡県人である. 約 20 年前に計測された北部九州の非都会的環境（農村など）に在住し た $2 つ の$ 異なった集団とこれらの女子学生の間に，足長（足型の長さ）に関して有意の 差は存在しなかったが，女子学生の身長は最も高く，また足指数（足型の長さに対する足 型の幅）は小さく足型は細長い形であった。これらの足型の特徴は，都会的な生活と世代 間の相違によるものと考えられる.

J. UOEH（産業医大誌)， 7 ( 3 ): 265-268 (1985) 